\title{
Immigration and Multiculturalism in Context: A Framework for Psychological Research
}

\author{
Colleen Ward ${ }^{1}$, Jessica Gale ${ }^{2}$, Christian Staerklé2 \& Jaimee Stuart ${ }^{3}$ \\ ${ }^{1}$ Victoria University of Wellington \\ ${ }^{2}$ University of Lausanne \\ ${ }^{3}$ Griffith University
}

Reference:

Ward, C., Gale, J., Staerklé, C., \& Stuart, J. (2018). Immigration and multiculturalism in context: A framework for psychological research. Journal of Social Issues.

Correspondence concerning this article should be addressed to Jessica Gale, Institute of Psychology, Quartier Mouline, Géopolis 5128, University of Lausanne, CH-1015 Lausanne, Switzerland. Contact : Jessica.Gale@unil.ch 


\begin{abstract}
Multiculturalism is a hotly debated issue in today's global arena. Much of the controversy arises due to different understandings of the term in public and political discourse. We argue that multiculturalism has three core components - diversity, ideology and policy - and that heterogeneous cultural groups in multicultural societies are ultimately seeking social justice, but in different ways. Moving beyond the broad social science research to the influences and impacts of multiculturalism within psychological studies, we introduce the concept of normative multiculturalism and propose an integrative framework, presenting multiculturalism as a contextual variable and examining its impact in terms of intergroup relations and subjective well-being. We also consider how multiculturalism at the societal level can be differentially experienced by immigrants and members of the receiving community. Finally, we discuss strategies for maximizing the benefits and minimizing the risks of multiculturalism, reconciling differing justice conceptions, and enhancing positive outcomes for the wider society.
\end{abstract}

Keywords: multiculturalism, diversity, immigration, integration-policy, social-justice, norms 


\section{Immigration and Multiculturalism in Context: A Framework for Psychological}

\section{Research}

Multiculturalism has become one of the most divisive issues in today's global arena. Proclaimed a failure in Germany, France and the United Kingdom, multiculturalism has been viewed as the cause of immigrants' social isolation and economic disadvantage, a significant threat to both national identity and liberal values, and a major contributor to social fragmentation (Joppke, 2014; Malik, 2015). This social rhetoric has led to a backlash against multiculturalism, particularly in Europe, where multiculturalism is now described as being “in retreat" (Banting \& Kymlicka, 2013). An alternative perspective has emerged in other parts of the world where multiculturalism is more often deemed a political success. Seen as a source of national identity and pride in Canada and Mauritius (Berry, 2013; Ng TseungWong \& Verkuyten, 2015), as a potential mechanism for nation-building in Australia (Moran, 2011; despite some critiques, see Boese \& Phillips, 2015; Walton et al., 2018) and as providing "the bedrock for a harmonious, stable and prosperous city-state" in Singapore (Noor \& Leong, 2013, p. 719), within these contexts, multiculturalism appears to deliver a range of positive social outcomes.

Much of the controversy over multiculturalism arises because of conceptual problems due to different understandings of the term in public and political discourse. In many instances multiculturalism is taken to simply refer to the presence of culturally diverse groups. In this paper, we argue that diversity is a necessary, but not sufficient, precondition for multiculturalism, and that multiculturalism is more about how cultural diversity is experienced and managed. At the most rudimentary level, multiculturalism rests on the combination of cultural diversity in the population, ideologies based on recognition and appreciation of this diversity, and policies and practices that accommodate it (Berry \& Ward, 
2016). Consequently, we require a more complex, multi-faceted approach to multiculturalism that examines the main and interactive effects of its major components in relation to its social, psychological and economic outcomes.

In social science research, particularly studies by sociologists and political scientists, the diversity, policy and ideology components of multiculturalism are typically assessed at the national level on the basis of objective archival data, including censuses, policy documents and national surveys. We suggest that a complementary psychological perspective on diversity, ideology and policy would be of benefit, a perspective that highlights individuals' observations, understandings, and interpretations of their everyday intercultural experiences, in addition to demographic, social or political facts (Berry \& Ward, 2016; Stuart \& Ward, 2018). Accordingly, we propose a framework for psychological research on multiculturalism. ${ }^{1}$ The framework highlights the importance of context, synthesizing interdisciplinary perspectives and incorporating objective indicators of a multicultural climate at the national level as well as individuals' normative perceptions of multiculturalism in terms of diversity, ideology and policy. The outcomes of multiculturalism are examined in terms of social connectedness, intergroup perceptions and relations, and subjective wellbeing. Within the framework, attention is given to the differential consequences of multiculturalism for majority and minority groups, the fundamental tensions between the rights of immigrants, including the rights to maintain cultural heritage, and the threat these rights pose to members of the receiving society (Green \& Staerklé, 2013). These tensions are elaborated in terms of power imbalances and individual and collective conceptualizations of justice (Gale \& Staerklé, 2017). Based on the synthesis of social psychological and cross-

\footnotetext{
${ }^{1}$ We use the term framework as described by Nilsen (2015) to refer to a structure or system of descriptive categories (i.e., constructs) and the relationships among them that account for phenomena or outcomes. As Nilsen's discussion of frameworks, models and theories occurs in the context of implementation science, which focuses on the goal of achieving evidence-based policies and practices, this is particularly appropriate for the analysis of multiculturalism.
} 
cultural research, we reiterate the challenges that multiculturalism presents, but conclude with recommendations for addressing concerns for justice and enhancing positive outcomes for immigrants and the societies in which they live.

\section{National Diversity, Ideology and Policy}

When Anders Breivik declared war on multiculturalism in July 2011, he left at least 77 people dead in Norway and his country in mourning. What did multiculturalism mean to him? Breivik is chronicled as being stridently anti-Muslim, based on his belief that Muslims were becoming a majority and that Christian Europe was under threat (Globe and Mail, 24 July, 2011). His views can be seen to reflect opposition to demographic diversity and a rejection of a multicultural ideology that is based on appreciation of that diversity. Along with other members of a far-right group, Breivik had grandiose plans to seize political power in Europe and implement a "cultural conservative political agenda" (New York Times, 24 July, 2011), reflecting extreme antagonism towards liberal multicultural policies. In the narrative of Anders Breivik the core diversity, ideology and policy elements of multiculturalism appear to be inextricably intertwined. This is often the case in everyday life where diversity, ideology and policy exert simultaneous and interactive effects on social and psychological outcomes, as elaborated in the remainder of this section.

Without doubt, the increase in immigration-driven heterogeneity has been a contentious issue in recent times whereby diversity has been linked to a range of negative psychological and social outcomes, including greater anti-immigrant sentiments, perceived threat, and hostile ethnic attitudes (Schneider, 2008). It has also been associated with lower levels of psychological well-being in both immigrants and majority group members (Longhi, 2014; Vedder, van de Vijver, \& Liebkind, 2006). Putnam's (2007) controversial research in the United States concluded that ethnic diversity reduces social solidarity and lowers trust and altruism although these findings have not been consistently replicated in international 
studies. Indeed, van der Meer and Tolsma's (2014) critical review concluded that ethnic diversity is not directly related to decrements in interethnic social cohesion (see also Kesler \& Bloemraad, 2010; Schmid, Al Ramiah, \& Hewstone, 2014), making it clear that increasing diversity does not inevitably lead to conflict, reductions in social capital or psychological distress.

Multicultural policies have also come under criticism in recent years, where it is often argued that multicultural practices are far from policy ideals, constrained by an assimilationist past (see Boese \& Phillips, 2015) and essentializing and creating segregation between groups (see Green \& Staerklé, 2013; Walton et al., 2018). But what does the empirical evidence tell us about the implications of these national policies in terms of social cohesion and well-being? Comparative political research provides the most robust approach to address these questions in studies that assess multicultural policies across a number of countries by using resources such as the Multicultural Policy Index (see Banting \& Kymlicka, 2013) and the Migrant Integration Policy Index (Migration Policy Group, 2011) to examine the relationship between these policies and their economic, social and psychological outcomes. This line of research points to the positive outcomes of multicultural policies for immigrants and ethnic minorities: lower immigrant-native wage gaps (Nieto, Matano, \& Ramos, 2013), more belongingness in terms of citizenship acquisition, higher levels of trust, lower levels of discrimination (Wright \& Bloemraad, 2012), and greater life satisfaction (Jackson \& Doerschler, 2016).

However, multicultural policies produce mixed effects for majority group members. The policies may be resented and seen as threatening, and under some circumstances they are associated with perceptions of greater discrimination and feelings of less safety by the majority group. At the same time, multicultural policies are related to a rise in majorities' satisfaction with life and with their national government (Jackson \& Doerschler, 2016). 
Schlueter, Meuleman and Davidov (2013) demonstrated that liberal policies for immigrant integration are associated with lower levels of perceived threat in their European study while Hooghe and de Vroome (2015) reported that multicultural policies are linked to lower levels of anti-immigrant sentiments. Jackson and Doerschler (2016) suggest that policies that offer both the maximum benefits to minorities and the least detriment to majorities may be the best way forward.

Beyond diversity and policy, ideology forms the third pillar of multiculturalism. In ideological terms multiculturalism reflects an appreciation of diversity and rests on the joint value placed on cultural maintenance and equitable participation. The ideological endorsement of the maintenance and participation principles of multiculturalism varies markedly across countries. With respect to cultural maintenance, findings from the Eurobarometer public opinion poll across 27 European countries indicates that agreement with the general premise that ethnic diversity enriches national culture varies from $32 \%$ in Malta to $86 \%$ in Sweden. In the case of equitable participation, the specific proposition that there should be more ethnic minority Members of Parliament received a lower level of endorsement ranging from 17\% in Bulgaria and Cyprus to $66 \%$ in Sweden and France (European Commission, 2007).

International comparative studies of multicultural ideology have largely concentrated on the national (e.g., GDP) and individual (e.g., age, income) level predictors of these attitudes. In some instances, however, studies have examined the outcomes of valuing diversity, most commonly in relation to attitudes toward immigrants and immigration. International Social Survey research has shown that those who appreciate cultural heterogeneity and support cultural maintenance in immigrant groups are willing to accept more immigrants (Ceobanu \& Escandell, 2010). Similarly, when diversity is viewed as beneficial, individuals have stronger pro-immigrant sentiments (O’Rourke \& Sinnott, 2006). 
In contrast, when there is resistance to diversity, there is also greater social distrust and perceived ethnic threat (Coenders, Lubbers, \& Scheepers, 2005).

\section{Psychological Contributions to the Multiculturalism Debate}

The discussion thus far has considered the three dimensions of multiculturalism based on national indicators of diversity (e.g., ethnic fractionalization), policy (e.g., the Multicultural Policy Index) and ideology (e.g., the International Social Survey Program). However, citizens are not always aware of national-level policies, and opinion polls have shown that diversity estimates are often out of line with population data (Transatlantic Trends, 2010). Consequently, individuals' perceptions of diversity, ideology and policy may be equally important in understanding the antecedents and consequences of multiculturalism. As such, psychology has much to contribute to contemporary discourses on multiculturalism.

\section{Multiculturalism and Everyday Experiences of Diversity: Contextual Factors and Perceived Norms}

A psychological perspective on the three core components of multiculturalism addresses a gap in our understanding of cultural diversity, intercultural contact, and their consequences by linking perceptions and interpretations of multiculturalism to cultural norms. Guimond, de la Sablonnière and Nugier (2014, p. 142) have argued that intercultural ideologies, including views of multiculturalism, are not "located solely in individual minds," but are shared by members of a social group and become normative. Norms act as social guides and provide the context for judging what is right and wrong, just and unjust (Green \& Staerklé, 2013). Norms also influence individuals' attitudes and behaviors, including intergroup perceptions and relations (Nesdale, Griffith, Durkin, \& Maas, 2005).

Guimond and colleagues were the first to propose that the relationship between national multicultural policies and the personal endorsement of multiculturalism is mediated by perceived multicultural norms (Guimond et al., 2013). Moreover, their causal model of 
intergroup attitudes in Canada, Germany, the United States and the United Kingdom demonstrated that country differences in anti-Muslim prejudice could not be adequately explained in terms of individual differences in support for multiculturalism, but was primarily dependent on perceived differences in multicultural norms across socio-political contexts. Although to date Guimond et al. $(2013,2014)$ have been the only researchers that have empirically investigated the relationship between national policies, perceived norms and outgroup prejudice, subsequent research has highlighted the importance of normative ideological climates and normative intercultural contact on intergroup relations (Fasel, Green, \& Sarrasin, 2013; Schachner, Brenick, Noack, van de Vijver, \& Heizmann, 2015). At regional, district and neighborhood levels normative positive intercultural contact is associated with decrements in individuals' out-group prejudice (Christ et al., 2014) and in the classroom, a climate of positive normative intercultural contact predicts more friendships between immigrant and native-born school children (Titzmann, Brenick, \& Silbereisen, 2015).

Stuart and Ward (2018) extended Guimond et al.’s (2013) line of research introducing the concept of normative multiculturalism, i.e., individuals' perceptions of a normative multicultural climate, defined in terms of: contact with diversity, multicultural ideology, and multicultural policies and practices. After constructing and validating a three-factor measure of Normative Multiculturalism, they examined the main and interactive effects of each dimension on social connectedness (trust, national attachment and perceived threat) in a predominantly White British sample. Their findings revealed that perceived normative multicultural ideology predicted greater national attachment and trust as well as lower levels of perceived threat. Perceived normative multicultural policies and practices also predicted greater national attachment, but were associated with greater threat perceptions. Of particular note was the interaction of the three facets of normative multiculturalism. Specifically, the association between policies and threat was attenuated under conditions of a strong normative 
multicultural ideology and normatively frequent intercultural contact. These results have significant implications: The three facets of normative multiculturalism operate in conjunction within a national context, and socio-political conditions can reduce perceptions that policies supporting cultural maintenance and equitable participation for immigrants are threatening to the majority.

There is also evidence that the dimensions of normative multiculturalism can play out differently across national contexts and between majority and minority groups. For example, perceived normative contact with diversity, multicultural policies and practices, and multicultural ideology all predict greater national attachment in the United States, but the positive effects of multicultural ideology are limited to Hispanic Americans and not found in Whites (Watters, Ward, \& Stuart, 2018). Although normative multiculturalism in the United Kingdom is generally associated with feelings of greater trust and belonging, lower levels of perceived discrimination and greater psychological well-being, normative multicultural policies and practices do predict greater perceived threat for Whites but (marginally) less perceived threat for Indians (Ward, Stuart, \& Watters, 2016).

\section{An Integrative Framework for the Psychological Study of Multiculturalism}

What is clear from the previous sections is that multiculturalism is a complex, multifaceted phenomenon, and its diversity, policy and ideological elements can be examined as objective indicators of a national context or in terms of perceived national multicultural norms. As will be discussed later in this section, multiculturalism can also be construed in terms of personal cultural ideologies. Moreover, the core dimensions of multiculturalism can exert differential effects on intercultural relations and subjective well-being. These critical points, as well as the importance of group status, are captured in our integrative framework, which situates key psychological processes and outcomes in a demographic, social and political context. 
Our framework is inspired by work by Guimond et al. (2013) and draws attention to the contextual antecedents of "everyday multiculturalism," that is, how diversity is experienced and evaluated (see Figure 1). Its major function is to integrate the empirical research on multiculturalism discussed in this paper rather than to represent a comprehensive model of psychological research on the antecedents and outcomes of multiculturalism. The framework highlights the importance of contextual elements - diversity, policy and ideology and how these elements not only exert direct effects on social and psychological outcomes, but also underpin psychological processes that link context to perceived social norms, norms to individuals' cultural ideologies, and ideologies to intercultural relations and subjective well-being. It differs from and extends Guimond et al.'s (2013) conceptual and empirical distinction between perceived multicultural norms and personal multicultural attitudes and the roles they play in intergroup relations by: 1) identifying three components of multiculturalism, both in terms of objective national criteria and subjectively perceived norms; 2) highlighting the role of group membership in key psychological processes and outcomes; and 3) incorporating well-being into the integrative framework (see also Ward, Szabo, \& Stuart, 2016).

The centrality of perceived multicultural norms. In keeping with Guimond et al. (2013), the framework presents the national socio-political context as an antecedent to perceived norms. In accordance with social and political research (e.g., Hooghe \& de Vroome, 2015; Jackson \& Doerschler, 2016), the national context is also depicted as exerting a direct influence on intergroup relations and well-being. However, psychological research suggests that the effects of perceived multicultural norms on these social and psychological outcomes, compared to the effects of national context, are more proximal and direct (e.g., Guimond et al. 2013, 2016; Stuart \& Ward, 2018). This is because norms define accepted standards of behavior and consequently function as a major source of social influence, as 
illustrated by Breugelmans and van de Vijver (2004), for example, who found that perceived norms for "multiculturalism as a threat" predicted decreased acceptance of multiculturalism and lower levels of out-group contact by majority group members while the reverse was true for normative "support for multiculturalism."

Based on Guimond et al.'s $(2013,2014)$ theory and research, the framework includes a path from perceived normative multiculturalism to personal cultural ideologies, findings that were also reported by Breugelmans and van de Vijver (2004) and by Stuart and Ward (2018). The mechanisms involved in the link between social norms and personal ideologies or behaviors have not been investigated specifically in relation to multiculturalism, and while there is a general consensus in the social and behavioral sciences that norms guide behaviors and attitudes, the underlying processes remain contentious. To these ends, Reynolds, Subašić and Tindall (2015) described four theoretical approaches to social norms and behavioral change: rational choice, evolutionary selection, the theory of planned behavior and internalization on the basis of social identity. These approaches differ in the extent to which norms are seen as internalized versus influenced via external forces and the extent to which emphasis is placed on social learning, conformity, cooperation, expectations, and selfinterest. However, Reynolds et al. (2015) make a strong case for a social identity approach as it specifies which “others" shape "our" norms (p. 50), which, in turn, create expectations for the alignment of our behaviors and attitudes with specific "others". This has clear relevance for the issue of group membership that is discussed below.

Finally, intergroup and well-being outcomes are predicted by personal cultural ideologies. Studies have shown that favorable attitudes toward multiculturalism are associated with stronger endorsement of policies that support social change for indigenous and minority groups and more liberal policies about the number and sources of immigrants (Urbiola, Willis, Ruiz-Romero, Moya, \& Esses, 2017; Ward \& Masgoret, 2008). The link 
between the personal endorsement of multiculturalism and positive intergroup experiences has been explained in terms of decreased out-group distance and perceived threat, greater tolerance of minorities, stronger egalitarian ideals, and a general belief that multiculturalism has positive consequences for society in general (Hui, Chen, Leung, \& Berry, 2015; Musso, Inguglia, Lo Coco, Albiero, \& Berry, 2017; Stupar, van de Vijver, Te Lindert, \& Fontaine, 2014; Ward \& Masgoret, 2006). Beyond this, personal cultural ideologies that are supportive of multiculturalism have also been related to more flexible acculturation expectations for both immigrant and native-born groups (Arends-Tóth \& van de Vijver, 2003) and to higher levels of self-esteem in minority and majority group members (Verkuyten, 2009).

The importance of group membership. Group membership occupies a central position in our framework. Status (i.e., majority versus minority and immigrant versus nativeborn) not only directly affects personal cultural ideologies, but also perceived multicultural norms, intergroup relations and subjective well-being. Furthermore, it moderates the relationships amongst these variables.

In liberal Western democracies there is strong evidence that ethnic minorities show more positive attitudes towards multiculturalism than national majorities (Arends-Tóth \& van de Vijver, 2003; Dandy \& Pe-Pua, 2010; van de Vijver, Breugelmans, \& Schalk-Soekar, 2008; Verkuyten, 2006; Ward \& Masgoret, 2008). These findings are in line with Social Identity Theory (SIT), which posits group membership can be a source of self-esteem and that individuals are motivated to protect and enhance the status of their in-group (Tajfel \& Turner, 1986). Given that ethnic minorities are often structurally disadvantaged relative to national majorities, the concrete implementation of multicultural policies can increase their group's status in society while allowing for the maintenance of their cultural identity (see Verkuyten, 2006). Beyond enhancing group status, ethnic minorities hold positive attitudes 
towards multiculturalism because it offers a sense of belonging and inclusion in a society where their cultural group is not the dominant one.

In contrast to minorities, majorities in many Western societies tend to have more neutral or ambivalent attitudes towards multiculturalism (van de Vijver et al., 2008; Verkuyten. 2006). There is a variety of intergroup theories that account for this trend. In addition to SIT (Tajfel \& Turner, 1986), Integrated Threat Theory (Stephan, Ybarra, \& Bachman, 1999), the Unified Instrumental Model of Group Conflict (Esses, Jackson, Dovidio, \& Hodson, 2005) and Social Dominance Theory (Sidanius \& Pratto, 1999) provide bases for interpreting these findings. In general, these theories suggest that opposition to multiculturalism arises from realistic and symbolic threat, competition for scarce resources, and the motivation to protect the in-group's dominant status. However, intergroup theory also points to contact with diverse others as diminishing the negative effects of threat and competition (Kotzur, Tropp, \& Wagner, 2018; Pettigrew \& Tropp, 2006), and research has shown that more frequent (positive) intercultural contact is associated with a greater valuing of diversity (Green, Fasel, \& Sarrasin, 2010; Hui et al., 2015).

Beyond the well-known factors highlighted in social psychological theories of intergroup relations, we suggest that divergent conceptions of justice may also contribute to majority-minority differences in the endorsement of multiculturalism. In Western democracies, individualistic values are fundamental and pervasive. They emphasize individual freedom, responsibility, rights and justice, underpin meritocratic principles, and operate in societies where "it is deemed legitimate to judge people according to their unique qualities, aptitudes and contributions, rather than according to their belonging to social categories" (Licata, Sanchez-Mazas, \& Green, 2011, p. 898). Majorities are especially sensitive to such principles while for immigrant and minority communities - who are keenly aware of the subordinate position they occupy in society - the group, rather than the 
individual, often assumes greater importance (Azzi, 1998; Green \& Staerklé, 2013).

Multiculturalism places emphasis on increasing equality and justice between groups as a supplement to the Western emphasis on justice between individuals. Not only is this collective group-based justice principle more appealing to immigrants and minorities, it is also seen as largely compatible with individual justice by members of these groups (Gale \& Staerklé, 2018). Majority groups in Western democracies, in contrast, are less aware of group membership and its implications and are more satisfied with principles and policies addressing individuals (see Azzi, 1998). They also see individualistic values and multiculturalism as relatively incompatible, believing that one might undermine the other. These findings provide additional insights into why majorities support multiculturalism less than minorities (Gale \& Staerklé, 2018).

As can be seen in our framework, majority-minority and immigrant-native differences extend beyond personal cultural ideologies to their antecedents and outcomes. There are notable differences in perceived multicultural norms between minority and majority groups. Hispanic-Americans and British Indians view contact with diversity as more normative than their white counterparts. Moreover, majority Whites in the United States, but not the United Kingdom, perceive normative multicultural ideology to be stronger than do minorities (Ward et al., 2016). With respect to social and psychological outcomes, national surveys have shown that there are often asymmetries in intergroup perceptions with majorities tending to be viewed more positively by minorities than the reverse (Sibley \& Ward, 2013), and life satisfaction has been found to be lower in immigrants compared to native-borns (Arpino \& de Valk, 2017).

Group status also moderates the associations of both national-level indicators of multiculturalism and perceived multicultural norms with intergroup attitudes and interactions. The contextual effects of national-level diversity and ideology often diverge for majority and 
minority groups as is the case for multicultural policies, which are associated with decrements in perceived discrimination for immigrants (Wright \& Bloemeraad, 2012), but increments for majorities (Jackson \& Doerschler, 2016). Moreover, while studies have shown that perceived normative multiculturalism, in general, has favorable consequences for both majorities and minorities in terms of greater social connectedness and well-being, the ideological component often has stronger positive effects for minorities while the policy dimension has more negative effects for majorities (Stuart \& Ward, 2018; Ward et al., 2016). The same is true for the moderating influence of group status on the associations between personal cultural ideologies and intergroup variables. In a study of native- and TurkishDutch, majority group members who endorsed multiculturalism were less likely to demand immigrant adoption of the national culture in public spheres while immigrants who endorsed multiculturalism were more willing to do so (Arends-Tóth \& van de Vijver, 2003). The role of group status in moderating the relationships between national level indicators of multiculturalism and perceived multicultural norms and between those perceived norms and personal cultural ideologies has not yet been investigated; this is a topic that should be considered in future research.

Strengths and limitations of the integrative framework. The framework presented here is limited in that it does not incorporate all of the demographic (e.g., education), dispositional (e.g., social dominance orientation) or situational (e.g., contact) predictors of cultural ideologies and intergroup relations. However, we believe it does highlight how psychological research can make important advances in our understanding of individual attitudes and experiences of multiculturalism embedded in context. This has been previously advocated by Fasel et al. (2013) with their emphasis on ideological climates, norms, and person x context interactions, and by Ward and Geeraert (2016) with their recommendation for more attention to process and context in acculturation research. It also provides an avenue 
for linking macro national-level research findings from sociology and political science to psychological studies of individuals' everyday experiences of multiculturalism. Moreover, we maintain that the framework has significant value for application, that is, recommending ways to maximize the benefits and minimize the risks of multiculturalism. This is discussed in the next section.

\section{Maximizing the Benefits and Minimizing the Risks of Multiculturalism}

Increased cultural diversity has become an objective reality throughout the Western world. As many have acknowledged before us, managing this cultural diversity to optimize intergroup harmony and to ensure a functional, just society for all its members is, therefore, crucial. Multiculturalism is, however, in the midst of a "global backlash" in which opposition has increased, and politicians claim that appropriate multicultural policies are difficult to implement effectively (Boese \& Phillips, 2015; Joppke, 2014). Despite claims of its failure, Banting and Kymlicka (2013) suggest that this discourse is not representative of the reality of global trends, with international research showing that policies are becoming increasingly multicultural, accommodating diversity and ensuring cultural maintenance while at the same time fostering engagement and participation in the wider society. Kymlicka (2013) warns that anti-multiculturalism rhetoric may still have negative repercussions however, as it can undermine an "inclusive sense of identity and belonging" despite the existence of policies, and a more positive "rhetoric may be an essential component of their success" (p. 108).

So where to from here, and what can psychology contribute to positive social change? To address these questions, two additional points warrant careful consideration: 1) at the contextual level multicultural policies and practices operate on the basis of the dual principles of cultural maintenance and participation; and 2) for multicultural success the expectations and needs of both majority and minority groups must be recognized and addressed. As a basis for recommending strategies to maximize the benefits and minimize the risks of 
multiculturalism, we discuss these issues in conjunction with key components of our framework, i.e., multicultural policies, multicultural norms and group membership.

\section{Introducing Multicultural Policies and Setting Multicultural Norms}

Given that multicultural policies at the national level affect intergroup relations and subjective well-being, at last partially through perceived cultural norms (Guimond et al., 2013, 2014; Jackson \& Doerschler, 2016), initiating and strengthening multicultural policies can lead to more positive social and psychological outcomes. Moreover, Nyborg et al. (2016) agree that policy can support social norm changes, but argue that this is more likely to occur in conjunction with "tipping points." Specifically, the probability of policy changing norms is increased if the norm changes are incentivized and involve highly visible behaviors, conditional cooperation (i.e., willingness to cooperate more when others cooperate more), social learning of personal moral responsibility by observing others, and receiving feedback on one's behavior. Green (2016), however, has argued that policy is less likely to precipitate norm change than activism.

Social psychological research has concentrated more on shifting perceived norms to change behaviors (Miller \& Prentice, 2016). This often involves "marketing social norms" by disseminating a message about the high incidence of desirable behavior among relevant group members (e.g., neighbors, classmates). Personalized normative feedback has also been used as an intervention strategy although in these cases the primary goal is to identify and correct inaccurate perceptions of objective norms. Most relevant to the discussion of normative multiculturalism appears to be theory and research on norms and public good, where an individual's behavior is seen as impacting the wider group. In these circumstances, those who share the same immediate circumstances or are in closer physical and geographical proximity make the most powerful normative reference group (Goldstein, Cialdini, \& Griskevicius, 2008). This suggests that multicultural norm-setting in organizations, 
educational institutions or even close-knit communities may be more effective than referencing national norms. As theory and research on normative multiculturalism are in the earliest stages, these issues deserve serious attention in future studies.

\section{Addressing Group Membership}

Common in-group identity. Feelings of belonging and an inclusive identity reflect multicultural ideals and are crucial for social cohesion and well-being. According to the Common In-group Identity Model (Gaertner, Dovidio, Anastasio, Bachman, \& Rust, 1993; Espinosa, 2018), an inclusive in-group identity is likely to arise when national majorities and ethnic minorities perceive commonalities between themselves. This can be encouraged in a variety of ways, including increasing intercultural contact. For example, studies have shown that normative contact with diversity is associated with stronger national identities in New Zealand and the United States (Stuart \& Ward, 2018), that social interaction among culturally diverse European students fosters a stronger European identity (Stoeckel, 2016) and that both Catholic and Protestant students in religiously integrated schools are more likely to identify as Northern Irish compared to those in segregated educational institutions (Hayes, McAllister, \& Dowds, 2007). Encouraging cooperation and interdependence during intergroup contact further supports a common identity (see Sherif, Harvey, White, Hood, \& Sherif, 1961) and is especially useful for improving intergroup relations in contexts where groups are in conflict or where "overt bigotry" is a norm (see Dovidio, Gaertner, Ufkes, Saguy, \& Pearson, 2016, p. 37). Research has also demonstrated that encouraging national majority group members to think about their similarities with ethnic minorities and their common superordinate group membership (e.g., an inclusive school, community or nation in which they live) can reduce in-group bias and prejudice and increase trust and support for pro-minority policies such as multiculturalism (see Dovidio et al., 2016, for a review). 
The dynamics of achieving a common in-group identity and its consequences are somewhat more complex for minority group members. In order to address and overcome group-based disparities and structural inequalities, ethnic minorities must also be permitted to maintain their sub-group cultural identity while identifying with the superordinate group. The resulting dual identification (González \& Brown, 2006; see also Berry \& Ward, 2016) can be promoted through contexts in which the superordinate group's representation encompasses complex (diverse, inclusive) prototypes (see Waldzus, Mummendey, Wenzel, \& Weber, 2003). Acknowledgement of cultural differences is precisely what allows for group-conscious multicultural policies such as affirmative action and minority rights to be implemented in contexts where intergroup relations are stable, where no systematic exclusion occurs, and where minorities are "more focused on achieving the promised inclusion in society, being treated fairly, and being respected for what makes them different as well as what they have in common with the majority group" (Dovidio et al., 2016, p. 37).

While minorities do tend to assume simultaneous identification with their ethnic group as well as the superordinate society, majorities are more accepting of superordinate identification with less emphasis on subgroups (Staerklé, Sidanius, Green, \& Molina, 2010). This is because identification with the superordinate society is often synonymous with majority group members' prototypical ethnic status (e.g., Devos \& Banaji, 2005), as well as their norms and belief systems. The paradox is that these belief systems are generally individualistic, rather than multicultural, bringing us into a discussion of recent research on justice conceptions from the perspective of groups experiencing power asymmetry, such as majorities versus minorities.

Justice considerations. Congruent with the idea that minorities tend to assume simultaneous identification with the superordinate society and their ethnic group, minorities also perceive compatibility between principles of individual justice such as meritocracy and 
principles of collective, group-based justice such as multiculturalism (Gale \& Staerklé, 2018). Majorities, on the other hand, tend to prefer superordinate identification where individualistic beliefs and individual justice principles can be emphasized, over subgroup identification where group-based justice can take precedence. Along these lines, recent work has shown that immigrant and low status group members are more supportive of multiculturalism than native and high-status group members only when they believe they live in a society which respects meritocratic, individual justice principles, where individuals are able to progress according to their own responsibility. In contrast, when members of immigrant groups feel they live in a socially stratified society in which group membership impedes individual progress, their support for multiculturalism can be significantly lower (while this is not the case for natives; see Gale \& Staerklé, 2018). This suggests that individual justice and multiculturalism must coexist for minorities to feel they live in a just society.

This line of research has implications for determining the ways in which to maximize the benefits and minimize the risks of multiculturalism in Western democracies. The findings suggest that ethnic minorities and national majorities not only perceive multiculturalism in fundamentally different ways, but they also experience and view the world, justice and society in different ways. If ethnic minorities are supportive of multiculturalism in a meritocratic society that emphasizes individual responsibility, then it is crucial to ensure both that individual justice principles are respected in a country (e.g., antidiscrimination, individual freedom and responsibility) and that collective forms of justice such as multiculturalism complement this individual justice. This is why the dual principles of cultural maintenance and societal participation inherent to multiculturalism are so important: For minorities, one cannot exist without the other. From a majority perspective, in contrast, we argue that in order to increase their support for multiculturalism, it needs to be framed in a 
way that matches their fundamental orientation towards individual justice, in which all members of society are taken into account. Therefore, when targeting majorities, relatively less emphasis should be placed on groups.

Diminishing majority resistance to multiculturalism. Majority groups are especially important to target when seeking to maximize the benefits of multiculturalism as they are, indeed, often resistant: For multiculturalism to be successful and for positive social change to occur, diversity, ideology and policy need the support of members of these dominant groups. But who exactly is this majority or dominant group?

Both in scientific literature and in everyday life, national majorities are defined as native, high status and numerical majority group members (Gale \& Staerklé, 2018). Taken together, these three criteria reflect the majority's powerful position in society. However, majority group members do not always match the three criteria at the same time. For example, while in most European countries the dominant group tends to be white and native, in nation states built on colonization and immigration such as Canada, the United States, Australia and New Zealand, the dominant group is composed of white people of European descent. This group is the numerical majority and is socially valued, but their ancestors were immigrants themselves and relative to them, native groups are generally disadvantaged and historically subordinate (Kymlicka, 1995). In such contexts, encouraging people to think of themselves in terms of their immigration origins (e.g., of European descent) instead of their race (e.g., White) can lead to less prejudice, stronger identification with ethnic minorities and greater support for multiculturalism (Morrison \& Chung, 2011).

Existing research shows that a number of other strategies can be used to increase majorities' or dominant group members' perception of justice in multiculturalism. For example, as Whites, relative to racial minorities in the United States, tend to associate multiculturalism with exclusion, it is important that multiculturalism is framed in an inclusive 
way, targeting all groups including the dominant one. Under these conditions, the association between multiculturalism and exclusion is reduced, and majorities show more positive attitudes towards cultural diversity (Plaut, Garnett, Buffardi, \& Sanchez-Burks, 2011). Such an inclusive approach to policy might also help overcome the issue that majorities feel more threatened when confronted with concrete multicultural policies to benefit minorities (e.g., the recognition and celebration of ethnic minorities' culture-specific festivals and holidays) as opposed to abstract multicultural principles that already appear more inclusive (e.g., valuing cultural diversity in general). Research shows that construing multiculturalism in concrete as opposed to abstract terms increases majorities' prejudice towards minority groups largely because they feel their national identity is threatened (Yogeeswaran \& Dasgupta, 2014). Diversity policies should use language that addresses all members of society, fostering feelings of inclusion for everyone, without the risk of excluding minority or majority group members (Stevens, Plaut, \& Sanchez-Burks, 2008).

Perceived threat is indeed a major determinant of majorities' opposition to multiculturalism that can also include perceived competition for resources such as jobs, money and power (see Esses, Jackson, \& Armstrong, 1998). A variety of situations can lead to such perceived competition, like increasing numbers of out-group members (e.g., in conditions where the national majority is a numerical minority) or the presence of highly skilled out-group members (e.g., when immigrants or ethnic minorities are of relatively high status). Scarcity of a resource (e.g., limited availability of jobs) or a desire for unequal distribution of resources (e.g., social dominance orientation) can also increase perceived competition (see also Thomsen, Green, \& Sidanius, 2008). Esses et al. (1998) suggest that encouraging the media to portray immigrants and ethnic minorities as a benefit to society (e.g., highly skilled people creating new jobs) and reframing zero-sum competition by directly targeting erroneous beliefs are ways to reduce such perceived threat and opposition 
to multiculturalism in these contexts. These strategies may allow for an increase in multicultural norms, perceived by majorities as respecting individual justice principles, and "a more inclusive national identity, over time" (Esses, Wagner, Wolf, Preiser, \& Wilbur, 2006, p. 666). They may also increase the likelihood that both majority and minority groups can reap the benefits of multiculturalism.

\section{Concluding Comments}

Multiculturalism is a complex, multi-faceted phenomena that has evoked intense and often acrimonious debate among policy-makers, social scientists and citizens. We contend that cultural diversity is a fundamental feature of multiculturalism, but that the ideological appreciation of this diversity and its accommodation by multicultural policies and practices that ensure cultural maintenance and inclusive, equitable participation are equally important. When viewed this way, multiculturalism has not failed; rather, most Western democracies have failed to become multicultural. This is not to advance a naively idealistic view of cultural diversity and intercultural contact. Multiculturalism may work, but multiculturalism is hard work. There are underlying tensions between individual and collective conceptions of justice; there are different costs and benefits for majority and minority groups; and there are massive discrepancies in national receptiveness to diversity. Despite these differences, we have offered a conceptual framework that integrates the contextual antecedents and the psycho-social outcomes of multiculturalism and have proposed directions for future research. Following this, we have also suggested approaches to maximize the benefits and minimize the risks of cultural diversity for both majorities and minorities. Although we have focused on national-level antecedents to perceived multicultural norms and their psychological and social outcomes in our discussion of multiculturalism, we believe the processes and outcomes are also relevant to school (Schachner et al., 2015; Titzmann et al., 2015) and community levels of analysis where intercultural interactions between immigrants and natives are often 
closer and more intimate (Huo, Dovidio, Jiménez, \& Schildkraut, 2018; Silka, 2018). In the end we hope that these reflections may go at least some way to understanding and resolving the challenges that multiculturalism currently presents in the global arena. 


\section{References}

Arends-Tóth, J., \& van de Vijver, F. J. R. (2003). Multiculturalism and acculturation: Views of Dutch and Turkish-Dutch. European Journal of Social Psychology, 33, 249-266. http://doi.org/10.1002/ejsp.143

Arpino, B., \& de Valk, H. A. G. (2017). Comparing life satisfaction of immigrants and natives across Europe: The role of social contacts. Social Indicators Research, 137(3), 1163-1184. doi:10.1007/s11205-017-1629-x

Azzi, A. E. (1998). From competitive interests, perceived injustice, and identity needs to collective action: Psychological mechanisms in ethnic nationalism. In C. Dandeker (Ed.), Nationalism and violence (pp. 73-138). New Brunswick, NJ: Transaction Press.

Banting, K., \& Kymlicka, W. (2013). Is there really a retreat from multiculturalism policies? New evidence from the multiculturalism policy index. Comparative European Politics, 11, 577-598. http://doi.org/10.1057/cep.2013.12

Berry, J. W. (2013). Research on multiculturalism in Canada. International Journal of Intercultural Relations, 37, 663-675. http://dx.doi.org/10.1016/j.ijintrel.2013.09.005

Berry, J. W., \& Ward, C. (2016). Multiculturalism. In D. L. Sam \& J. W. Berry (Eds.), The Cambridge handbook of acculturation psychology ( $2^{\text {nd }}$ ed., pp. 441-463). Cambridge: Cambridge University Press.

Boese, M., \& Phillips, M. (2015). Multiculturalising at the interface of policy and practice. In F. Mansouri (Ed.), Cultural, religious and political contestations (pp. 205-222). Basel, Switzerland: Springer. doi: 10.1007/978-3-319-16003-0_13

Breugelmans, S. M., \& van de Vijver, F. J. R. (2004). Attitudes toward multiculturalism in the Netherlands. Applied Psychology: An International Review, 53, 400-422. doi:10.1111/j.1464- 0597.2004.00177.x 
Ceobanu, A. M., \& Escandell. X. (2010). Comparative analysis of public attitudes toward immigrants and immigration using multinational survey data: A review of theories and research. Annual Review of Sociology, 36, 309-328. doi:

10.1146/annurev.soc.012809.102651

Christ, O., Schmid, K., Lolliot, S., Swart, H., Stolle, D., Tausch, N., Al Ramiah, A....Hewstone, M. (2014). Contextual effect of positive intergroup contact on outgroup prejudice. Proceedings of the National Academy of Sciences of the United States of America, 111 (11), 3996-4000. https://doi.org/10.1073/pnas. 1320901111

Coenders, M., Lubbers, M., \& Scheepers, P. (2005). Majority populations' attitudes toward migrants and minorities in Western and Eastern European societies: Results from the European Social Survey 2002-2003. Vienna: European Monitoring Center on Racism and Xenophobia.

Dandy, J., \& Pe-Pua, R. (2010). Attitudes to multiculturalism, immigration and cultural diversity: Comparison of dominant and non-dominant groups in three Australian states. International Journal of Intercultural Relations, 34, 34-46. http://doi.org/10.1016/j.ijintrel.2009.10.003

Devos, T., \& Banaji, M. R. (2005). American = White? Journal of Personality and Social Psychology, 88, 447-466. http://doi.org/10.1037/0022-3514.88.3.447

Dovidio, J. F., Gaertner, S. L., Ufkes, E. G., Saguy, T., \& Pearson, A. R. (2016). Included but invisible? Subtle bias, common identity, and the darker side of "we." Social Issues and Policy Review, 10, 6-46. http://doi.org/10.1111/sipr.12017

Espinosa, A., Guerra, R., Sanatkar, S., Paolini, S., Damigella, D., Liccardello, O., \& Gaertner, S. (2018). Identity inclusiveness and compatibility and attitudes toward immigrants and immigration policy. Journal of Social Issues, 74(4), xxx-xxx.

Esses, V. M., Jackson, L. M., \& Armstrong, T. L. (1998). Intergroup competition and 
attitudes toward immigrants and immigration: An Instrumental Model of Group Conflict. Journal of Social Issues, 54, 699-724. http://doi.org/10.1111/j.15404560.1998.tb01244.x

Esses, V.. M., Jackson, L. M., Dovidio, J. F., \& Hodson, G. (2005). Instrumental relations among groups: Group competition, conflict and prejudice. In J. F. Dovidio, P. Glick, \& L. A. Rudman (Eds.), On the nature of prejudice: Fifty years after Allport (pp. 227243). Malden, MA: Blackwell. doi:10.1002/9780470773963.ch14

Esses, V. M., Wagner, U., Wolf, C., Preiser, M., \& Wilbur, C. J. (2006). Perceptions of national identity and attitudes toward immigrants and immigration in Canada and Germany. International Journal of Intercultural Relations, 30, 653-669. http://doi.org/10.1016/j.ijintrel.2006.07.002

European Commission. (2007). Eurobarometer: Discrimination in the European Union. Retrieved from http://ec.europa.eu/public_opinion/archives/ebs/ebs_263_en.pdf.

Fasel, N., Green, E. G. T., \& Sarrasin, O. (2013). Facing cultural diversity: Anti-immigrant attitudes in Europe. European Psychologist, 18, 253-262. http://dx.doi.org/10.1027/1016-9040/a000157

Gaertner, S. L., Dovidio, J. F., Anastasio, P. A., Bachman, B. A., \& Rust, M. C. (1993). The common in-group identity model: Recategorization and the reduction of intergroup bias. European Review of Social Psychology, 4, 1-26. https://doi.org/10.1080/14792779343000004

Gale, J., \& Staerklé, C. (2017). Multiculturalisme et justice sociale. In C. Staerklé \& F. Butera (Eds.), Conflits constructifs, conflits destructifs : Regards psychosociaux (pp. 205-220). Lausanne, Switzerland: Editions Antipodes.

Gale, J., \& Staerklé, C. (2018). Multiculturalism in liberal societies: Group membership and compatibility between individual and collective justice. Manuscript submitted for 
publication.

Globe and Mail. (24 July, 2011). Norway gunman's manifesto calls for war against Muslims. Retrieved from https://www.theglobeandmail.com/news/world/norway-gunmans$\underline{\text { manifesto-calls-for-war-against-muslims/article588098/ }}$

Goldstein, N. J., Cialdini, R. B., \& Griskevicius, V. (2008). Room with a viewpoint: Using norm-based appeals to motivate conservation behaviors in a hotel setting. Journal of Consumer Research, 35, 472-482. Doi: 10.1086/586910

González, R., \& Brown, R. (2006). Dual identities in intergroup contact: Group status and size moderate the generalization of positive attitude change. Journal of Experimental Social Psychology, 42, 753-767. doi: 10.1016/j.jesp.2005.11.008

Green, D. (2016). How change happens. Oxord: Oxford Scholarship Online. doi: 10.1093/acprof:oso/9780198785392.001.0001

Green, E. G. T., Fasel, N., \& Sarrasin, O. (2010). The more the merrier? The effects of type of cultural diversity on exclusionary immigration attitudes in Switzerland. International Journal of Conflict and Violence, 4, 178-190. doi:10.4119/UNIBI/ijcv.79

Green, E. G. T., \& Staerklé, C. (2013). Migration and multiculturalism. In L. Huddy, D. O. Sears, \& J. S. Levy (Eds.), Oxford handbook of political psychology (2nd ed., pp. 852-889). Oxford: Oxford University Press.

Guimond, S., Crisp, R. J., De Oliveira, P., Kamiejski, R., Kteily, N., Kuepper, B., Lalonde, R. N....Zick, A. (2013). Diversity policy, social dominance, and intergroup relations: Predicting prejudice in changing social and political contexts. Journal of Personality and Social Psychology, 104, 941-958. http://doi.org/10.1037/a0032069 
Guimond, S., de la Sablonnière, R., \& Nugier, A. (2014). Living in a multicultural world: Intergroup ideologies and the societal context of intergroup relations. European Review of Social Psychology, 25, 142-188. doi:10.1080/10463283.2014.957578

Hayes, B. C., McAllister, I., \& Dowds, L. (2014). Integrated education, intergroup relations and political identities in Northern Ireland. Social Problems, 44, 454-482. doi: 10.1525/sp.2007.54.4.454

Hooghe, M., \& de Vroome, T. (2015). How does the majority public react to multiculturalist policies? A comparative analysis of European countries. American Behavioral Scientist, 59, 747-768. http://doi.org/10.1177/0002764214566499

Hui, B. P. H., Chen, S. X., Leung, C. M., \& Berry, J. W. (2015). Facilitating adaptation and intercultural contact: The role of integration and multicultural ideology in dominant and non-dominant groups. International Journal of Intercultural Relations, 45, 70-84. http://doi.org/10.1016/j.ijintrel.2015.01.002

Huo, Y. J., Dovidio, J. F., Jiménez, T., \& Schildkraut, D. (2018). Do local policies that welcome immigrants polarize or unify immigrant-receiving communities? Journal of Social Issues, 74 (4), xxx-xxx.

Jackson. P. I., \& Doerschler, P. (2016). How safe do majority group members, ethnic minorities and Muslims feel in multicultural European societies? Democracy and Security, 12, 247-277. https://doi.org/10.1080/17419166.2016.1213165

Joppke, C. (2014). The retreat is real- but what is the alternative? Multiculturalism, muscular liberalism and Islam. Constellations, 21, 296-295. doi: 10.111/1467-8675

Kesler, C., \& Bloemraad, I. (2010). Does immigration erode social capital? The conditional effects of immigration-generated diversity of trust, membership, and participation across 19 countries, 1981-2000. Canadian Journal of Political Science, 43, 319-347. https://doi.org/10.1017/S0008423910000077 
Kotzur, P. F., Tropp. L. R., \& Wagner, U. (2018). Welcoming the unwelcome: Contact and immigration in Germany and the United States. Journal of Social Issues, 74 (4), xxx$\mathrm{xxx}$.

Kymlicka, W. (1995). Multicultural citizenship. Oxford, UK: Clarendon.

Kymlicka, W. (2013). Neoliberal multiculturalism? In P. A. Hall \& M. Lamont (Eds.), Social resilience in the neoliberal era (pp. 99-125). Cambridge: Cambridge University Press.

Licata, L., Sanchez-Mazas, M., \& Green, E. G. T. (2011). Identity, immigration, and prejudice in Europe: A recognition approach. In S. J. Schwartz, K. Luyckx, \& V. L. Vignoles (Eds.), Handbook of identity theory and research, Vol 2: Domains and categories (pp. 895-916). New York: Springer. http://doi.org/10.1007/978-1-44197988-9_38

Longhi, S. (2014). Cultural diversity and subjective well-being. IZA Journal of Migration, 3(13), 1-19. https://doi.org/10.1186/2193-9039-3-13

Malik, K. (2015). The failure of multiculturalism: Community versus society in Europe. Foreign Affairs, 94(2), 21-32.

Migration Policy Group. (2011) The Migrant Integration Policy Index (MIPEX). Brussels: Migration Policy Group/British Council.

Moran, A. (2011). Multiculturalism as nation-building in Australia: Inclusive national identity and the embrace of diversity. Ethnic and Racial Studies, 34(12), 2153-2172. doi: $10.1080 / 01419870.2011 .573081$

Morrison, K. R., \& Chung, A. H. (2011). "White" or "European American"? Self-identifying labels influence majority group members' interethnic attitudes. Journal of Experimental Social Psychology, 47, 165-170. http://doi.org/10.1016/j.jesp.2010.07.019 
Musso, P., Inguglia, C., Lo Coco, A., Albiero, P., \& Berry, J. W. (2017). Mediating and moderating processes in the relationship between multicultural ideology and attitudes towards immigrants in emerging adults. International Journal of Psychology, 52, 7277. http://doi.org/10.1002/ijop.12290

Nesdale, D., Griffith, J., Durkin, K., \& Maass, A. (2005). Empathy, group norms and children's ethnic attitudes. Applied Developmental Psychology, 26, 623-637. http://dx.doi.org/10.1016/j.appdev.2005.08.003

New York Times. (July 24, 2011). Oslo suspect wrote of fear of Islam and plan for war. Retrieved from http://www.nytimes.com/2011/07/24/world/europe/24oslo.html

Ng Tseung-Wong, C. \& Verkuyten, M. (2015). Multiculturalism, Mauritian style: Cultural diversity, belonging and a secular state. American Behavioral Scientist, 59, 679-701. doi: abs/10.1177/0002764214566498

Nieto, S., Matano, A., \& Ramos, R. (2013). Skill mismatches in the EU: Immigrants versus natives. Discussion Paper 7701. Institute for the Study of Labour (IZA), Bonn, Germany. Retrieved from http://ftp.iza.org/dp7701.pdf.

Nilsen, P. (2015). Making sense of implementation theories, models and frameworks. Implementation Science, 10, 53 - 66. doi: 10.1186/s13012-015-0242-0

Noor, N. M., \& Leong, C.-H. (2013). Multiculturalism in Malaysia and Singapore: Contesting models. International Journal of Intercultural Relations, 37, 714-726. http://dx.doi.org/10.1016/j.ijnrtrel.2013.09.009

Nyborg, K., Anderies, J. M., Dannenberg, N., Lindahl, T., Schill, C., Schlüter, M...de Zeeuw, A. (2016). Social norms as solutions. Science, 354(6308), 42-43. doi: 10.1126.science.aaf8317 
O'Rourke, K. H., \& Sinnott, R. (2006). The determinants of individual attitudes toward immigration. European Journal of Political Economy, 22, 838-861. doi:10.1016/j.ejpoleco.2005.10.005

Pettigrew, T. F., \& Tropp, L. R. (2006). A meta-analytic test of intergroup contact theory. Journal of Personality and Social Psychology, 90, 751-783. http://doi.org/10.1037/0022-3514.90.5.751

Plaut, V. C., Garnett, F. G., Buffardi, L. E., \& Sanchez-Burks, J. (2011). "What about me?” Perceptions of exclusion and whites' reactions to multiculturalism. Journal of Personality and Social Psychology, 101, 337-53. http://doi.org/10.1037/a0022832

Putnam, R. (2007). E Pluribus Unum: Diversity and community in the Twenty-first century. Scandinavian Political Studies, 30, 137-174. doi/10.1111/j.1467-9477.2007.00176.x

Reynolds, K. J., Subašić, E., \& Tindal, K. (2015). The problem of behavior change: From social norms to an ingroup focus. Social and Personality Psychology Compass, 9(1), 45-56. doi:10.1111/spc3. 12155

Schachner, M. K., Brenick, A., Noack, P., van de Vijver, F. J. R., \& Heizmann, B. (2015). Structural and normative conditions for interethnic friendships in multiethnic classrooms. International Journal of Intercultural Relations, 47, 1-12. http://dx.doi.org/10.1016/j.ijintrel.2015.02.003

Schlueter, E., Meuleman, B., \& Davidov, E. (2013). Immigrant integration policies and perceived group threat: A multi-level study of 27 Western and Eastern European countries. Social Science Research, 42, 670-682. doi: 10.1016/j.ssresearch.2012.12.001

Schmid, K., Al Ramiah, A., \& Hewstone, M. (2014). Neighborhood ethnic diversity and trust: The role of intergroup contact and perceived threat. Psychological Science, 25, 665-674. https://doi.org/10.1177/0956797613508956 
Schneider, S. L. (2008). Anti-immigrant attitudes in Europe: Outgroup size and perceived ethnic threat. European Sociological Review, 24, 53-67. https://doiorg.helicon.vuw.ac.nz/10.1093/esr/jcm034

Sherif, M., Harvey, O. J., White, J. B., Hood, W. R., \& Sherif, C. W. (1961). Intergroup conflict and cooperation: The robbers cave experiment. Norman: Oklahoma University Press.

Sibley, C. G., \& Ward, C. (2013). Mapping the state of the nation: A barometer test of New Zealand's multicultural status. International Journal of Intercultural Relations, 37, 700-713. http://dx.doi.org/10.1016/j.ijintrel.2013.09.008

Sidanius, J., \& Pratto, F. (1999). Social dominance: An intergroup theory of social hierarchy and oppression. Cambridge, UK: Cambridge University Press.

Silka, L. (2018). The immigrant experience at the community level: Implications for policy. Journal of Social Issues, 74 (4), xxx-xxx.

Simon, B., Aufderheide, B., \& Kampmeier, C. (2001). The social psychology of minoritymajority relations. In R. Brown \& S. Gaertner (Eds.), Blackwell handbook of social psychology: Intergroup processes (pp. 303-323). Malden, MA: Blackwell.

Staerklé, C., Sidanius, J., Green, E. G. T., \& Molina, L. E. (2010). Ethnic minority-majority asymmetry in nation attitudes around the world: A multilevel analysis. Political Psychology, 31, 491-519. http://dx.doi.org/10.1111/j.1467-9221.2010.00766.x

Stephan, W. G., Ybarra, O., \& Bachman, G. (1999). Prejudice toward immigrants. Journal of Applied Social Psychology, 29, 2221-2237. http://doi.org/10.1111/j.15591816.1999.tb00107.x

Stevens, F. G., Plaut, V. C., \& Sanchez-Burks, J. (2008). Unlocking the benefits of diversity: All-inclusive multiculturalism and positive organizational change. The Journal of Applied Behavioral Science, 44, 116-133. http://doi.org/10.1177/0021886308314460 
Stoeckel, F. (2016). Contact and community: The role of social interactions for a political identity. Political Psychology, 37, 431-442. doi: 10.1111/pops.1295

Stuart, J., \& Ward, C. (2018). Exploring everyday experiences of cultural diversity: The construction, validation and application of the Normative Multiculturalism Scale. European Journal of Social Psychology. https://doi.org/10.1002/ejsp.2542

Stupar, S., van de Vijver, F. J. R., Te Lindert, A., \& Fontaine, R. J. (2014). Multicultural attitudes mediate the relation between personality and perceived outgroup distance in the Netherlands. International Journal of Intercultural Relations, 38, 24-35. http://dx.doi.org/10.1016/j.ijintrel.2013.05.002

Tajfel, H., \& Turner, J. C. (1986). The social identity theory of intergroup behavior. In S. Worchel \& W. G. Austin (Eds.), Psychology of intergroup relations (2nd ed., pp. 724). Chicago: Nelson-Hall.

Thomsen, L., Green, E. G. T., \& Sidanius, J. (2008). We will hunt them down: How social dominance orientation and right-wing authoritarianism fuel ethnic persecution of immigrants in fundamentally different ways. Journal of Experimental Social Psychology, 44, 1455-1464. http://doi.org/10.1016/j.jesp.2008.06.011

Titzmann, P. F., Brenick, A., \& Silbereisen, R. K. (2015). Friendships fighting prejudice: A longitudinal perspective on adolescents' cross-group friendships with immigrants. Journal of Youth and Adolescents, 44, 1318-1331. https://doi.org/10.1007/s10964015-0256-6

Transatlantic Trends. (2010). Immigration. Retrieved from http://trends.gmfus.org/files/archived/immigration/doc/TTI2010_English_Key.pdf.

Urbiola, A., Willis, G. B., Ruiz-Romero, J., Moya, M., \& Esses, V. (2017). Valuing diversity in Spain and Canada: The role of multicultural ideology in intergroup attitudes and intentions to reduce inequalities. International Journal of Intercultural Relations, 56, 
25-38. http://doi.org/10.1016/j.ijintrel.2016.10.006

van de Vijver, F. J. R., Breugelmans, S. M., \& Schalk-Soekar, S. R. G. (2008).

Multiculturalism: Construct validity and stability. International Journal of Intercultural Relations, 32, 93-104. http://doi.org/10.1016/j.ijintrel.2007.11.001

van der Meer, T., \& Tolsma, J. (2014). Ethnic diversity and its effects on social cohesion. Annual Review of Sociology, 40, 459-478. https://doi.org/10.1146/annurev-soc071913-043309

Vedder, P., van de Vijver, F. J. R., \& Liebkind, K. (2006). Predicting immigrant youths’ adaptation across countries and ethno-cultural groups. In J. W. Berry, J. S. Phinney, D. L. Sam, \& P. Vedder (Eds.), Immigrant youth in cultural transition: Acculturation, identity and adaptation across national contexts (pp. 143-165). Mahwah, NJ:

Lawrence Erlbaum.

Verkuyten, M. (2006). Multicultural recognition and ethnic minority rights: A social identity perspective. European Review of Social Psychology, 17, 148-184. http://doi.org/10.1080/10463280600937418

Verkuyten, M. (2009). Self-esteem and multiculturalism: An examination among ethnic minority and majority groups in the Netherlands. Journal of Research in Personality, 43, 419-427. http://doi.org/10.1016/j.jrp.2009.01.013

Waldzus, S., Mummendey, A., Wenzel, M., \& Weber, U. (2003). Towards tolerance: Representations of superordinate categories and perceived ingroup prototypicality. Journal of Experimental Social Psychology, 39, 31-47. doi: 10.1016/S0022-

\section{1(02)00507-3.}

Walton, J., Priest, N., Kowal, E., White, F., Fox, B., \& Paradies, Y. (2018). Whiteness and national identity: Teachers' discourses in Australian primary schools. Race, Ethnicity and Education, 21, 132-147. doi: 10.1080/13613324.2016.1195357 
Ward, C., \& Geeraert, N. (2016). Advancing acculturation theory and research: The acculturation process in its ecological context. Current Opinion in Psychology, 8, 98104. http://dx.doi.org/10.1016/j.copsyc.2015.09.021

Ward, C., \& Masgoret, A. M. (2006). An integrative model of attitudes toward immigrants. International Journal of Intercultural Relations, 30, 671-682. http://doi.org/10.1016/j.ijintrel.2006.06.002

Ward, C., \& Masgoret, A.-M. (2008). Attitudes toward immigrants, immigration and multiculturalism in New Zealand. International Migration Review, 42, 222-243. doi: 10o.1111/j.1747-7379.2007.00119.x

Ward, C., Stuart, J., \& Watters, S. M. (2016, December). Multiculturalism: The cause of social problems or the cure for social ills? Paper presented at the SPSSI-SASP Small Group Meeting on Immigration to Major Immigrant-receiving Countries. Ottawa, Canada.

Ward, C., Szabo, A., \& Stuart, J. (2016). Prejudice against immigrants in multicultural societies. In C. S. Sibley \& F. K. Barlow (Eds.), The Cambridge handbook of prejudice (pp. 413437). Cambridge, UK: Cambridge University Press.

Watters, S. M., Ward, C., \& Stuart, J. (2018). Does normative multiculturalism foster or threaten social cohesion? Manuscript submitted for publication.

Wright, S., \& Bloemraad, I. (2012). Is there a trade-off between multiculturalism and sociopolitical integration? Policy regimes and immigrant incorporation in comparative perspective. Perspectives on Politics, 10, 77-95. doi: 10.1017/S1537592711004919

Yogeeswaran, K., \& Dasgupta, N. (2014). The devil is in the details: Abstract versus concrete construals of multiculturalism differentially impact intergroup relations. Journal of Personality and Social Psychology, 106, 772-89. http://doi.org/10.1037/a0035830 


\section{Author Bios}

Colleen Ward is Professor of Psychology and Founding Director of the Centre for Applied Cross-cultural Research, Victoria University of Wellington, New Zealand. Her research interests are focused on cultures in contact, and she has published widely on immigration, acculturation and intercultural relations. Applying her research to contemporary social issues, Colleen has provided consultancy to government bodies and NGOs in New Zealand, including the Office of Ethnic Communities, the Human Rights Commission, Immigration New Zealand, and Multicultural New Zealand. In 2011 she was awarded the Royal Society of New Zealand's prestigious Te Rangi Hiroa medal for her research on cultural diversity. Colleen is a former President of the International Academy for Intercultural Research (200911) and former Editor-in-Chief of the International Journal of Intercultural Relations (201214). She is currently an Honorary Fellow and the President-Elect of the International Association for Cross-cultural Psychology; she is also a member of the International Advisory Board for Global MINDS, an Erasmus Mundus-funded joint Master degree in the Psychology of Global Mobility, Inclusion and Diversity in Society

Jessica Gale is a doctoral student and teaching assistant at the University of Lausanne in Switzerland. Her research interests lie in multicultural opinion formation from a social psychological perspective. With experimental and international survey studies, she currently analyses the extent to which multicultural principles and policies are compatible with various individual and group-based forms of social justice. She obtained her BA at Trent University in 2010 and her BEd at Queen's University in Canada in 2011, and has been affiliated with the University of Lausanne since 2011 where she also obtained an MSc in 2014. 
Christian Staerklé is Associate Professor of Social Psychology at the University of Lausanne in Switzerland and docent of social psychology at the University of Helsinki in Finland. Using survey, experimental, and qualitative methods, his research studies opinion formation in the domains of social welfare, social control, institutional legitimacy and multiculturalism, both from a comparative perspective and within countries. He also investigates national and ethnic identities in a cross-cultural context and life course transitions in various youth populations in Switzerland. He has widely published on intergroup attitudes, cultural beliefs and political legitimacy and has obtained many research grants from national and international research organizations. Staerklé is codirector of the social psychology graduate school of the universities of Geneva and Lausanne, and is currently associate editor of the British Journal of Social Psychology and of the Swiss Journal of Psychology.

Jaimee Stuart is a Lecturer in the School of Applied Psychology at Griffith University. She is a developmental and cultural psychologist who specalises in adolescent wellbeing and identity development at the intersection of social and technological change. She has widely published in the area of promotion of positive outcomes for diverse and vulnerable youth and the examination of socio-cultural contexts as influences on development. Her recent research projects have examined issues such as bullying, immigration, religiosity, discrimination, sexuality, peer interactions and family relationships. She also maintains strong interests in methodology and employs both advanced quantitative and qualitative analytics. Jaimee is currently an Adjunct Fellow at both the Roy McKenzie Centre for the Study of Families and the Centre for Applied Cross-Cultural Research at Victoria University of Wellington, New Zealand, and an Associate Editor for the International Journal of Intercultural Relations. 
National Level:

Individual Level: Psychological and Social Factors

Contextual Factors

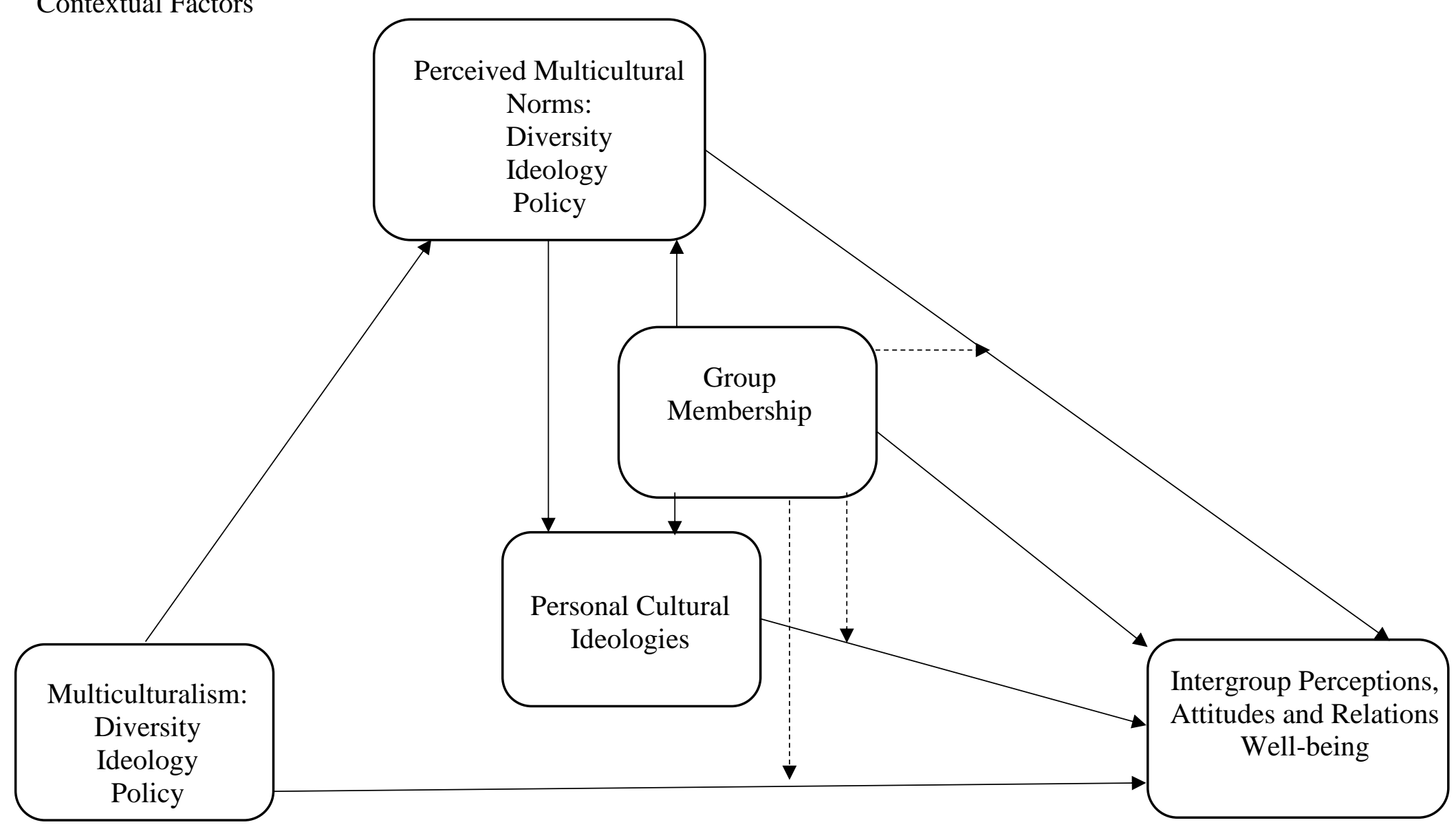

Figure 1. An integrative framework for the psychological study of multiculturalism. 